\title{
PEMANFAATAN GOOGLE CLASSROOM PADA PEMBELAJARAN IPA JARAK JAUH UNTUK MENINGKATKAN KETERAMPILAN KOMUNIKASI PESERTA DIDIK
}

\author{
Novika Lestari Handayani, Dwi Sulisworo, Ishafit \\ Program Studi Magister Pendidikan Fisika, Universitas Ahmad Dahlan \\ Email: vika.alghazi21@gmail.com
}

Diterima: 1 Februari 2021. Direvisi: 17 Maret 2021. Disetujui: 20 Maret 2021.

\begin{abstract}
Abstrak
Di masa pandemi seperti sekarang ini perlu adanya inovasi pembelajaran yang disampaikan melalui jarak jauh. Salah satu sistem informasi yang dapat digunakan untuk pembelajaran jarak jauh yaitu sistem manajemen pembelajaran atau learning management systems (LMS). Pembelajaran melalui LMS diharapkan dapat diakses oleh peserta didik kapanpun dan dimanapun. Ada beberapa LMS yang sudah familiar di kalangan pendidikan, salah satunya adalah LMS google classroom. Tujuan dari penelitian ini adalah untuk mengetahui peningkatan keterampilan komunikasi peserta didik melalui pemanfaatan google classroom sebagai LMS pembelajaran IPA jarak jauh pada materi pesawat sederhana menggunakan simulasi PhET. Penggunaan simulasi PhET ini disertai LKPD untuk membantu proses pembelajaran. Peserta didik dapat mengikuti prosedur pembelajaran yang disampaikan melalui google classroom dan LKPD Simulasi PhET. Keterampilan komunikasi peserta didik diukur melalui angket sebelum dan setelah pembelajaran menggunakan LMS google classroom. Berdasarkan penelitian yang telah dilakukan $92 \%$ peserta didik aktif mengikuti pembelajaran virtual melalui LMS google classroom dengan peningkatan keterampilan komunikasi peserta didik sebesar 6,7\%.
\end{abstract}

Kata Kunci: LMS, fisika, google classroom, keterampilan komunikasi.

\begin{abstract}
In this pandemics era, it is necessary to have an innovation for distance learning. One of the information systems that can be used for distance learning is the learning management system (LMS). LMS is expected to be accessible to students anytime and anywhere. There are several LMS that are familiar in education, one of which is Google Classroom. This study aimed to determine the improvement of students' communication skills by using Google Classroom as LMS for distance physics learning and using PhET simulations. A worksheet accompanies this PhET stimulation to help with the learning process. Students can follow the learning procedures are delivered on Google Classroom and PhET Simulation Worksheet. Students' communication skills are measured through a questionnaire before and after learning by Google Classroom. Based on research that has been done, $92 \%$ of students are active participants in virtual learning through Google Classroom, with 6.7\% increase in students communication skills.
\end{abstract}

Keywords: LMS, physics, google classroom, communication skills 
Handayani., Sulisworo., Ishafit. - Pemanfaatan Google Classroom...

\section{PENDAHULUAN}

Pada masa pandemi seperti sekarang ini perlu adanya inovasi pembelajaran jarak jauh. Pembelajaran jarak jauh yang dimaksud dapat memfasilitasi tatap maya antara guru dan peserta didik dalam jaringan. Pembelajaran jarak jauh secara daring ini dapat disampaikan melalui sistem informasi, salah satunya sistem manajemen pembelajaran.

Sistem manajemen pembelajaran atau learning management system (LMS) merupakan salah satu jenis sistem informasi khusus yang pemanfaatannya fokus pada pembelajaran (Wang et al, 2007). LMS atau sistem manajemen pembelajaran merupakan fitur yang memungkinkan sekelompok pendidik dan peserta didik berbagi materi pembelajaran melalui interaksi baik sinkron maupun asinkron (Vovides et al., 2007). LMS merupakan suatu infrastruktur online yang mentransfer dan mendistribusikan bahan ajar dari pendidik kepada peserta didik untuk melaksanakan pembelajaran, mendefinisikan serta mengevaluasi pembelajaran dan target pendidikan, mengikuti proses pembelajaran sesuai target yang akan dicapai, mengumpulkan dan menyajikan data untuk mengontrol proses pembelajaran secara keseluruhan (Faith \& Burak, 2017). Melalui LMS, pendidik (narasumber) dapat membagikan berbagai format, seperti video, kuis, LKPD, maupun forum diskusi secara online untuk mendukung proses pembelajaran (Lee \& Chun, 2018).

Pada beberapa institusi di negara maju, LMS berhasil meningkatkan motivasi dan hasil belajar peserta didik, mengurangi jumlah peserta didik putus sekolah, serta meningkatkan kepuasan peserta didik pada pembelajaran melalui LMS dengan berbagai fitur yang ditawarkan (Naveh et al, 2012). Melalui LMS pendidik dan peserta didik dapat saling berbagi pengetahuan melalui forum diskusi virtual (MacGilivray, 2004). Forum diskusi virtual ini merupakan sistem yang relatif terbuka sehingga memungkinkan interaksi yang aktif baik antara pendidik dan peserta didik maupun antar peserta didik. 
Handayani., Sulisworo., Ishafit. - Pemanfaatan Google Classroom...

Tentunya, forum diskusi virtual ini berdasarkan materi yang sudah dibagikan pada LMS tertentu oleh pendidik sebagai narasumber (Nagi \& Charmonman, 2008).

Pada masa pandemi seperti sekarang ini, beberapa institusi pendidikan menggabungkan pembelajaran virtual melalui LMS dengan pembelajaran tatap muka secara langsung yang disebut blended learning. Pembelajaran dengan model seperti ini tentu memperhatikan kondisi geografis sekolah dengan tempat tinggal peserta didik (Andersson \& Gronlund, 2009). Misalkan saja di daerah pedalaman yang relatif sulit mendapat jaringan internet dapat melakukan blended learning ini sehingga pembelajaran dapat dilakukan secara online dan offline.

Penggunaan LMS untuk proses pembelajaran tentu membutuhkan sumber daya yang memadai supaya dapat dimanfaatkan secara efektif. Keterbatasan sumber daya untuk memanfaatkan LMS hanya akan memicu kegagalan proses pembelajaran karena pelaksanaannya tentu tidak maksimal (Heeks, 2002).
Untuk memaksimalkan penggunaan LMS dalam proses pembelajaran, institusi atau sekolah dapat memanfaatkan layanan media sosial untuk melengkapi fitur LMS dan berkomunikasi antar pengguna LMS tersebut (Dube \& Scott, 2014). LMS untuk proses pembelajaran akan lebih mudah digunakan jika layanan LMS tersebut dapat diakses melalui ponsel atau smartphone. Akses LMS melalui ponsel tentu lebih praktis dan dapat digunakan dimanapun dan kapanpun. Hal ini untuk memberikan alternative juga kepada pengguna LMS yang tidak memiliki perangkat komputer (Ssekakubo et al., 2014).

Keberhasilan suatu LMS dalam proses pembelajaran sangat ditentukan oleh kepuasan pendidik dan peserta didik sebagai pengguna LMS. Selain itu, kualitas dan kesiapan informasi pada LMS serta fitur-fitur pembelajaran mandiri juga mempengaruhi keberhasilan penggunaan LMS untuk pembelajaran (Tella, 2012; Eom, 2014). Pengguna yang puas dengan suatu LMS cenderung sedikit mengeluh setelah menggunakan LMS bahkan akan menggunakannya kembali di 
Handayani., Sulisworo., Ishafit. - Pemanfaatan Google Classroom...

pembelajaran selanjutnya (Tarigan, 2011). Oleh karena itu, keberhasilan penggunaan LMS dapat diamati dalam hal intensitas dan kualitas penggunaannya (Joel, 2015).

Pada tahun 2014, Google memperkenalkan platform khusus yang digunakan sebagai LMS untuk membantu pelaksanaan pembelajaran yaitu google classroom. Google classroom membantu guru untuk membuat dan mengatur tugas kelas dengan cepat dan mudah, memberikan umpan balik kepada siswa langsung secara efisien, dan berkomunikasi bersama siswa tanpa terbatas oleh ruang dan waktu. Google classroom dianggap sebagai platform terbaik yang mampu meningkatkan kinerja guru. Google classroom menyediakan fasilitas yang sangat bermanfaat yang dapat dimanfaatkan oleh siswa. Google classroom membantu guru untuk mengatur kelas, memanfaatkan waktu dan meningkatkan kualitas komunikasi dengan siswa (Latif, 2016).

Hakim (2016) menyatakan bahwa LMS google classroom ini menggunakan jaringan internet yang dapat diakses menggunakan komputer dan/atau telepon seluler. Harapannya, sistem pembelajaran ini dapat meningkatkan keterampilan komunikasi peserta didik pada proses pembelajaran karena media ini dapat menampilkan teks, gambar, dan video pada saat proses pembelajaran berlangsung. Selain itu, media ini dapat menampung dan mengatur waktu pengumpulan tugas oleh guru yang tentunya akan menumbuhkan kedisiplinan bagi peserta didik dalam mengerjakan tugas. Sehingga, tujuan penelitian ini adalah untuk mengetahui keaktifan peserta didik dan peningkatan keterampilan komunikasi selama proses pembelajaran dengan memanfaatkan aplikasi google classroom dapat terwujud.

Swita dan Heri (2019) mengutarakan dalam praktik penggunaannya, google classroom sangat mudah untuk digunakan dalam pembelajaran. Selain mudah diakses dan digunakan, LMS ini dapat menjadi ruang berkomunikasi dan berinteraksi antara guru dan peserta didik dalam kelas maya. Baik guru maupun peserta didik dapat 
Handayani., Sulisworo., Ishafit. - Pemanfaatan Google Classroom...

menggunakan berbagai fitur yang disediakan oleh google classroom untuk memaksimalkan pembelajaran jarak jauh.

. Penelitian oleh Swita \& Heri (2019) menjelaskan bahwa Google classroom merupakan LMS berbasis aplikasi yang dapat dimanfaatkan sebagai platform manajemen pembelajaran online. Aplikasi ini dilengkapi berbagai fitur yang dapat dimanfaatkan sebagai fasilitas pendukung proses pembelajaran. Aplikasi ini sering digunakan sebagai pendukung pada proses pembelajaran konvensional, blended-learning, maupun online (Hapsari, \& Pamungkas, 2019; Nurfalah, 2019; Zurimi, 2019). Selain itu, google classroom merupakan salah satu aplikasi yang dapat digunakan sebagai LMS dan bersifat fleksibel, aplikasi ini dapat diimplementasikan pada materi saintik, sochum, dan materi-materi pembelajaran yang terkait dengan teknologi informasi dan komunikasi (Hapsari, 2019; Tumengkol, 2020).

Pada pemanfaatan fitur-fitur google classroom untuk pembelajaran jarak jauh, LMS ini dapat juga dikolaborasikan dengan laboratorium virtual melalui Simulasi PhET Colorado. Simulasi PhET ini tersedia secara online dan offline (dengan mendownload aplikasi terlebih dahulu) sehingga dapat digunakan oleh guru dan peserta didik dimanapun dan kapanpun. Tentu dalam menggunakan simulasi PhET ini disertai lembar kerja peserta didik (LKPD) sebagai panduan dalam melakukan simulasi.

Pembelajaran dengan menggunakan simulasi PhET membuat peserta didik tertarik dan lebih semangat melakukan praktikum sehingga menuntaskan hasil belajar peserta didik Di samping itu pembelajaran fisika dengan menggunakan multimedia interaktif PhET memberikan hasil belajar lebih baik daripada kelas yang hanya menggunakan praktikum saja tanpa disertai penggunaan media PhET (Mubarrok \& Mulyaningsih, 2014).

Permasalahan keterampilan komunikasi peserta didik yang cenderung pasif di dalam kelas dapat disebabkan oleh berbagai faktor. Menurut Lunenburg (2010), faktor atau hambatan dalam berkomunikasi 
Handayani., Sulisworo., Ishafit. - Pemanfaatan Google Classroom...

ada 4, yaitu hambatan proses menggunakan banyak sumber) untuk penyampaian, hambatan fisik, hambatan semantik, dan hambatan psikososial. Hambatan proses disebabkan guru tidak sepenuhnya mengerti pesan berupa materi pembelajaran yang disampaikan kepada peserta didik dapat diterima atau belum. Hambatan fisik meliputi jarak antara guru dan peserta didik yang berkomunikasi, suasana yang terlalu ramai, dan gangguan pada media komunikasi. Hambatan semantik berupa hambatan bahasa. Pemilihan kata yang tidak tepat dan penggunaan bahasa yang berbeda antara guru dengan peserta didik dapat menyebabkan terjadinya perbedaan pemahaman. Hambatan psikososial merupakan hambatan psikologis dan sosial yang meliputi rasa empati, kebiasaan, adat istiadat, harapan, kebutuhan, persepsi, dan kebudayaan.

Keterampilan komunikasi menurut Greenstein (2012) meliputi aspek penyampaian pesan dari guru kepada peserta didik atau sebaliknya, mau menerima komunikasi (membaca, mendengar, berpendapat, dan menyatakan ide.

Indikator keterampilan komunikasi yang akan diukur adalah (1) mencari informasi; (2) mendengarkan dan mengamati; (3) menulis ilmiah; (4) merepresentasi informasi; dan (5) mempresentasikan pengetahuan.

Tujuan penelitian ini adalah mengetahui pemanfaatan LMS google classroom pada pembelajaran IPA jarak jauh materi Pesawat Sederhana Jenis Tuas untuk meningkatkan keterampilan komunikasi peserta didik kelas VIII SMP.

\section{METODE}

Pada awal pembelajaran, guru memberikan sosialisasi mengenai penggunaan google classroom kepada peserta didik melalui WhatsApp Grup. Selanjutnya guru memastikan setiap peserta didik sudah memiliki akun di Google Classroom yang selanjutnya peserta didik dapat belajar, menyimak, membaca dan mengirim tugas dari jarak jauh. Tahapan berikutnya yaitu pelaksanaan pembelajaran melalui LMS google classroom meliputi persiapan, pelaksanaan, dan evaluasi. 
Handayani., Sulisworo., Ishafit. - Pemanfaatan Google Classroom...

Adapun rancangan pembelajaran Gambar 1 dan tahapan pelaksanaan menggunakan LMS google classroom pembelajaran pada Gambar 2. digambarkan oleh diagram pada

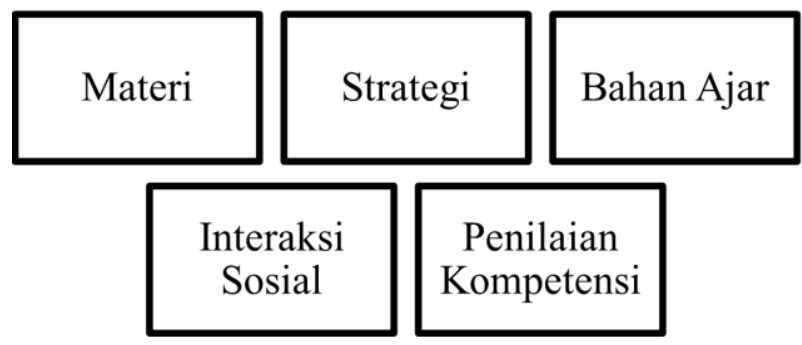

Gambar 1. Rancangan Pembelajaran

Materi pokok yang dipilih untuk penelitian menggunakan LMS google classroom ini adalah Gaya dan Hukum Newton dengan sub materi Pesawat Sederhana Jenis Tuas. Strategi yang digunakan adalah strategi pembelajaran jarak jauh melalui google classroom. Bahan ajar yang digunakan dalam pembelajaran meliputi buku paket IPA Fisika SMP Kelas VIII, Modul Blended Learning IPA Kelas VIII khusus masa pandemi, LKPD Simulasi PhET, Aplikasi laboratorium virtual PhET Colorado pada tema Balancing Act. Interaksi sosial yang dapat dilaksanakan melalui pembelajaran jarak jauh ini yaitu komunikasi antara guru dan peserta didik melalui google classroom serta proses pelaporan hasil belajar peserta didik kepada guru. Penilaian kompetensi yang dapat diukur melalui proses pembelajaran ini meliputi penilaian hasil eksperimen virtual (simulasi) menggunakan $\mathrm{PhET}$ sesuai prosedur pada LKPD serta pengukuran keterampilan komunikasi peserta didik sebelum dan sesudah menggunakan google classroom.

Tahapan pelaksanaan pembelajaran sebagaimana diilustrasikan pada Gambar 2 dapat dijabarkan sebagai berikut. Tahap persiapan

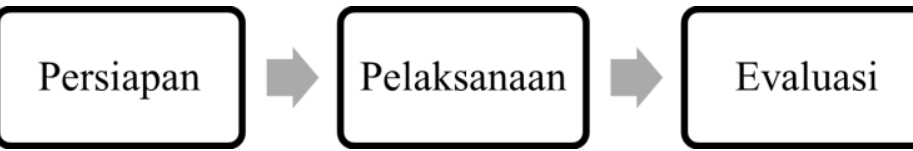

Gambar 2. Tahapan Pelaksanaan Pembelajaran 
Handayani., Sulisworo., Ishafit. - Pemanfaatan Google Classroom...

meliputi (1) guru membuat akun pembelajaran di google classroom; (2) guru mensosialisasikan penggunaan google classroom kepada peserta didik termasuk kode kelas untuk pembelajaran IPA Fisika; (3) guru menyampaikan prosedur pembelajaran IPA Fisika melalui google classroom; dan (4) guru mengunggah materi pembelajaran pada google classroom yaitu pada sub materi Pesawat Sederhana Jenis Tuas termasuk buku Paket IPA Fisika dan Modul Blended Learning IPA SMP yang digunakan sebagai acuan utama, LKPD panduan Simulasi PhET Balancing Act serta alamat website Simulasi PhET dengan tema Balancing Act.

Tahap pelaksanaan meliputi (1) guru menyampaikan materi pembelajaran melalui google cassroom yaitu pada sub materi Pesawat Sederhana Jenis Tuas. Penyampaian materi ini dibantu dengan video pembelajaran supaya peserta didik lebih mudah memahami materi pembelajaran sebagai prasyarat materi selanjutnya; (2) peserta didik melaksanakan pembelajaran sesuai dengan prosedur yang disampaikan guru pada google classroom maupun LKPD yang disediakan; dan (3) peserta didik melakukan diskusi pada google classroom baik dengan guru maupun antar peserta didik selama pembelajaran jarak jauh berlangsung.

Tahap evaluasi meliputi penilaian hasil belajar peserta didik yang telah dilakukan melalui google classroom secara langsung dan tes tulis melalui google form serta (2) penilaian keterampilan komunikasi peserta didik sebelum dan setelah pembelajaran menggunakan google classroom menggunakan angket pada google form untuk mengetahui peningkatan keterampilan komunikasi peserta didik.

\section{HASIL DAN PEMBAHASAN}

Penelitian dilaksanakan pada semester gasal tahun pelajaran 2020/2021. Populasi yang digunakan dalam penelitian adalah peserta didik kelas VIII SMP Muhammadiyah 3 Depok yang terdiri dari 4 kelas paralel dengan jumlah 142 peserta didik.

Pembelajaran jarak jauh melalui google classroom dapat memotivasi keaktifan peserta didik dalam 
Handayani., Sulisworo., Ishafit. - Pemanfaatan Google Classroom...

pembelajaran melalui berbagai fitur yang tersedia pada LMS tersebut (Swita \& Heri, 2019). Seperti dinyatakan oleh Hakim (2016) google classroom melatih peserta didik supaya dapat belajar lebih mandiri dan disiplin. Peserta didik mengikuti pembelajaran sesuai jadwal yang telah ditentukan dan mengumpulkan hasil belajarnya sesuai jadwal tersebut.

Proses pembelajaran melalui google classroom ini diawali dengan koordinasi atau pengarahan oleh guru melalui WhatsApp Grup pembelajaran IPA Fisika. WhatstApp Grup ini digunakan oleh guru dan peserta didik untuk berkomunikasi saat persiapan, pelaksanaan maupun setelah melaksanakan pembelajaran. Penggunaan aplikasi ini sebagai media sosial yang membantu proses pembelajaran pada google classroom.

Peserta didik dapat mengakses berbagai media dan bahan ajar yang diunggah oleh guru sebagai pendamping proses pembelajaran serta dapat mengirimkan kembali hasil belajarnya sebagai bahan evaluasi oleh guru sebagai bahan pengukuran keterampilan komunikasi peserta didik melalui LMS. Tampilan google classroom pada penelitian ini seperti ditunjukkan pada Gambar 3.

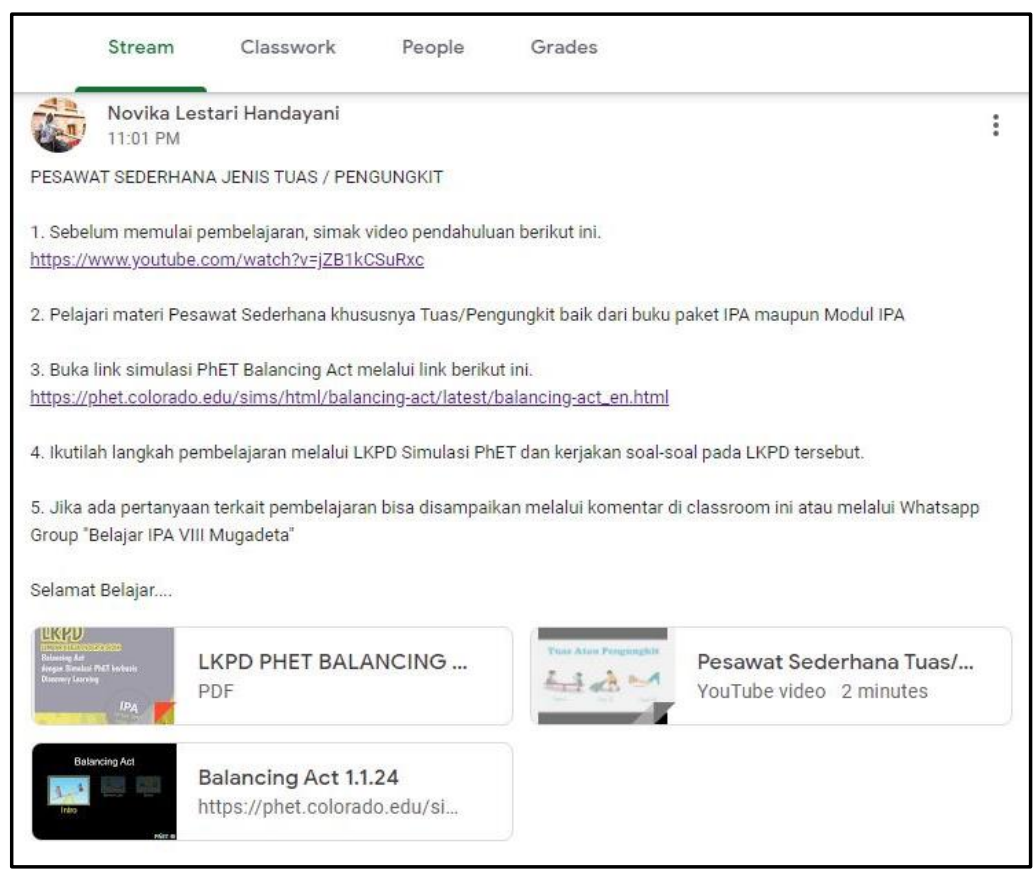

Gambar 3. Tampilan Prosedur Pembelajaran pada Google Classroom 
Handayani., Sulisworo., Ishafit. - Pemanfaatan Google Classroom...

Pembelajaran dilaksanakan dengan memanfaatkan fitur-fitur pada google classroom untuk menampilkan prosedur yang harus dilakukan peserta didik selama pelajaran berlangsung. Pada tampilan google classroom ini tersedia juga alamat website, bahan ajar, maupun mediamedia yang digunakan selama pembelajaran. Selain itu, guru dan peserta didik dapat berkomunikasi atau berdiskusi pada LMS ini melalui fitur chatting. Gambar 4 merupakan tampilan aplikasi laboratorium virtual PhET Colorado yang digunakan oleh peserta didik untuk melakukan simulasi maupun eksperimen secara virtual sesuai prosedur pada google classroom. Aplikasi PhET ini menyediakan berbagai aktivitas simulasi dan eksperimen sains. Pada pembelajaran jarak jauh kali ini guru memilih topik Balancing Act yang sesuai dengan pokok bahasan Pesawat Sederhana Jenis Tuas.

Dalam menggunakan simulasi PhET tersebut, guru menyediakan LKPD sebagai bahan ajarnya. LKPD ini dibuat oleh guru sebagai panduan peserta didik saat melaksanakan simulasi dan eksperimen melalui aplikasi PhET. LKPD ini menjelaskan fitur-fitur serta prosedur pada aplikasi laboratorium virtual PhET. Simulasi yang dipilih yaitu pada topik Balancing Act yang mensimulasikan prinsip kerja pesawat sederhana jenis tuas atau pengungkit.

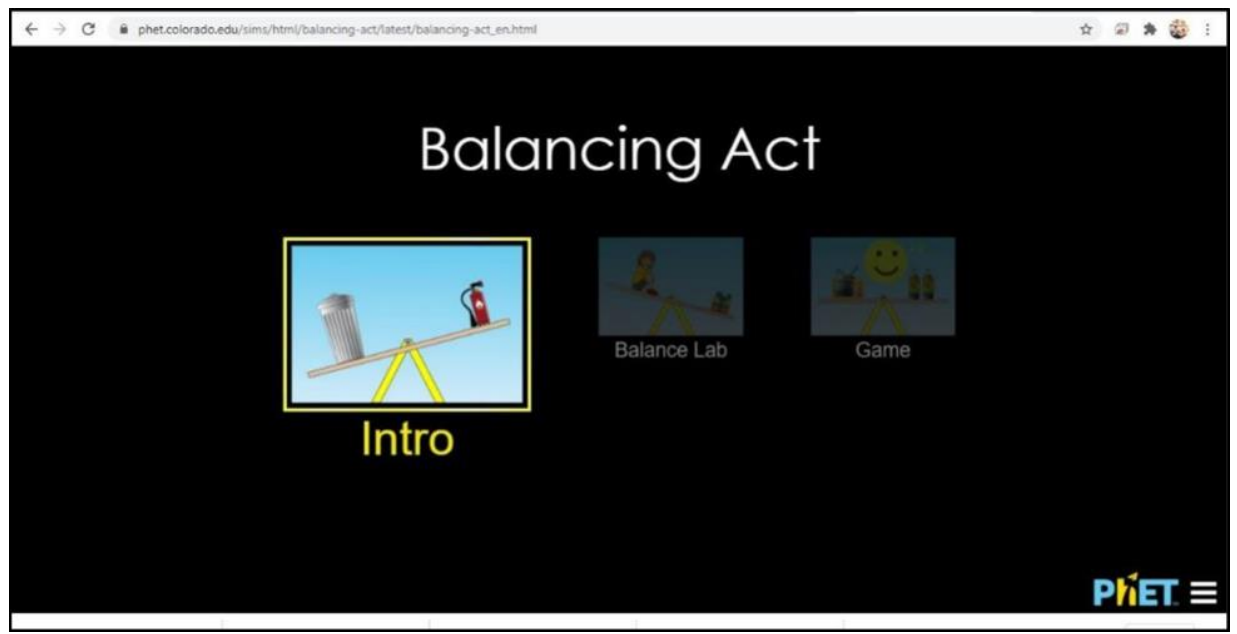

Gambar 4. Tampilan Aplikasi Laboratorium Virtual PhET Colorado 
Handayani., Sulisworo., Ishafit. - Pemanfaatan Google Classroom...

Selain itu, LKPD ini memuat pada google classroom. Gambar 5 di evaluasi hasil simulasi dan atas merupakan salah satu tampilan eksperimen yang berupa pertanyaan- $\quad$ LKPD simulasi PhET. pertanyaan uraian untuk dijawab oleh peserta didik dan hasilnya diupload

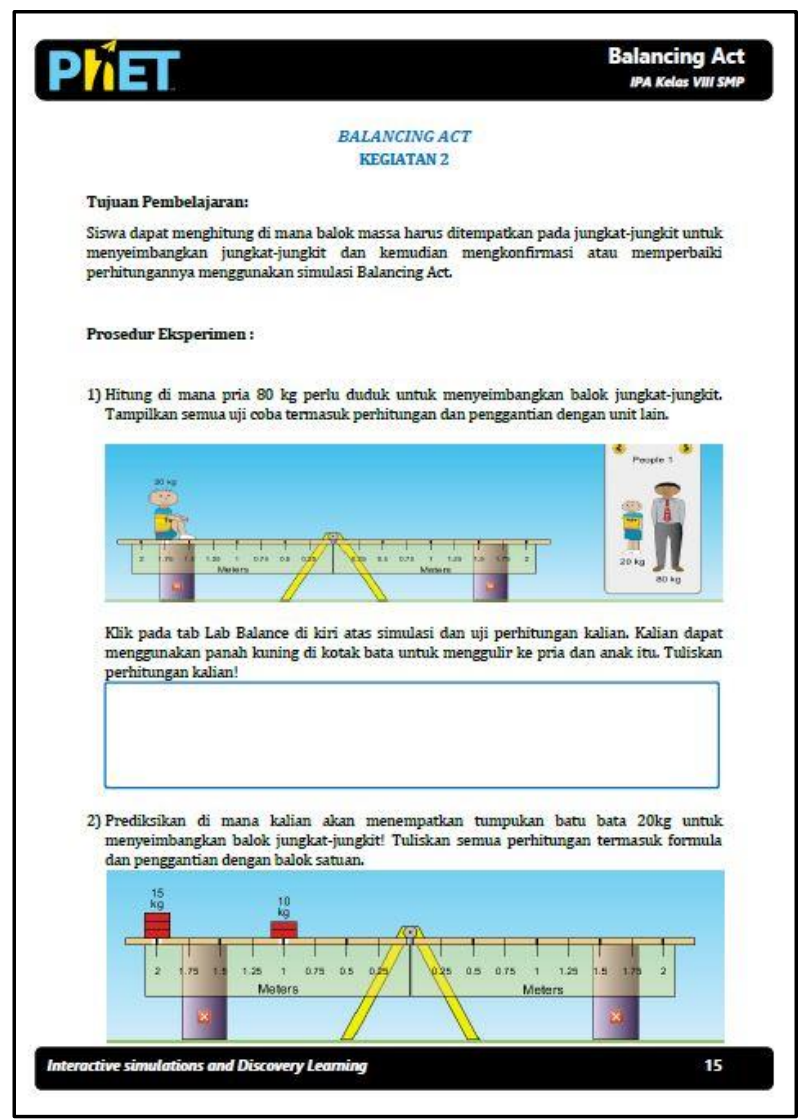

Gambar 5. Tampilan LKPD PhET Balancing Act

Hasil keaktifan peserta didik jumlah peserta didik kelas VIII dapat seperti pada diagram yang mengikuti pembelajaran secara online ditampilkan oleh Gambar 6 sedangkan sisanya 12 peserta didik menunjukkan bahwa pelaksanaan atau $8 \%$ tidak dapat berpartisipasi pembelajaran melalui LMS google melalui google classroom classroom pada materi Pesawat dikarenakan beberapa kendala Sederhana Jenis Tuas yaitu sebanyak diantaranya jaringan internet yang 130 peserta didik atau 92\% dari kurang lancar, belum mahir dalam 
Handayani., Sulisworo., Ishafit. - Pemanfaatan Google Classroom...

menggunakan google classroom, pandemi ini yang mengharuskan terkendala email dan password yang pembelajaran jarak jauh. Dari data tidak dapat digunakan, serta tersebut terlihat 2 peserta didik perangkat pembelajaran (smartphone) menyatakan tidak puas menggunakan yang belum mendukung untuk LMS ini dikarenakan peserta didik menggunakan LMS ini.

Hasil angket kepuasan peserta tersebut belum memiliki smartphone maupun laptop yang mendukung didik dalam menggunakan LMS untuk mengakses google classroom. google classroom untuk pembelajaran yang ditampilkan pada diagram

Keterampilan komunikasi peserta didik diobservasi menggunakan

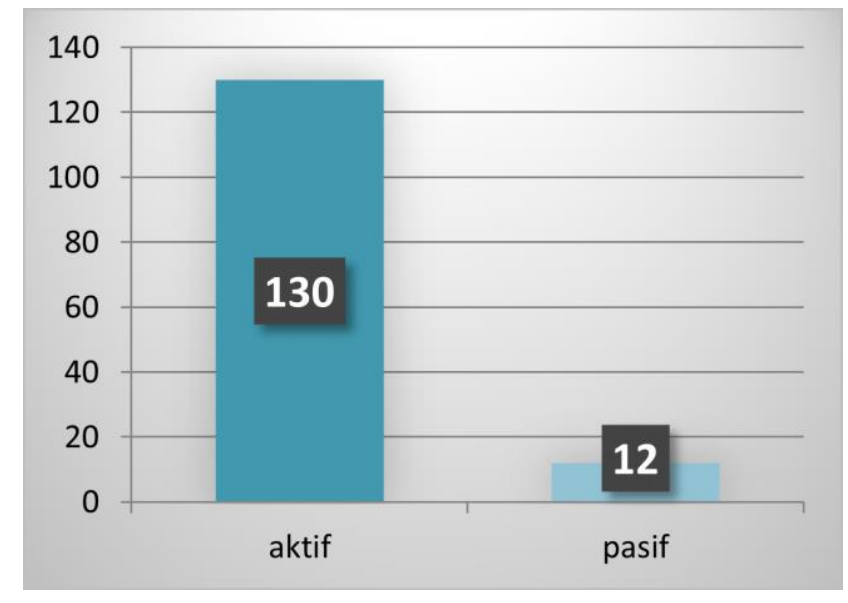

Gambar 6. Diagram hasil keaktifan peserta didik dalam pembelajaran

Gambar 7 menunjukkan bahwa 16\% peserta didik menyatakan sangat puas, $27 \%$ menyatakan puas, $44 \%$ menyatakan cukup puas, $11 \%$ menyatakan kurang puas dan $2 \%$ menyatakan tidak puas. Tentu sebagian besar peserta didik cukup puas menggunakan LMS ini sehingga cukup efektif untuk digunakan dalam pembelajaran khususnya masa angket dan tes akhir pada proses pembelajaran. Berdasarkan hasil observasi sebelum dan setelah menggunakan LMS google classroom, keterampilan komunikasi peserta didik meningkat sebanyak $6,7 \%$. Hal ini menunjukkan bahwa pembelajaran melalui LMS dapat meningkatkan keterampilan komunikasi peserta didik. 
Handayani., Sulisworo., Ishafit. - Pemanfaatan Google Classroom...

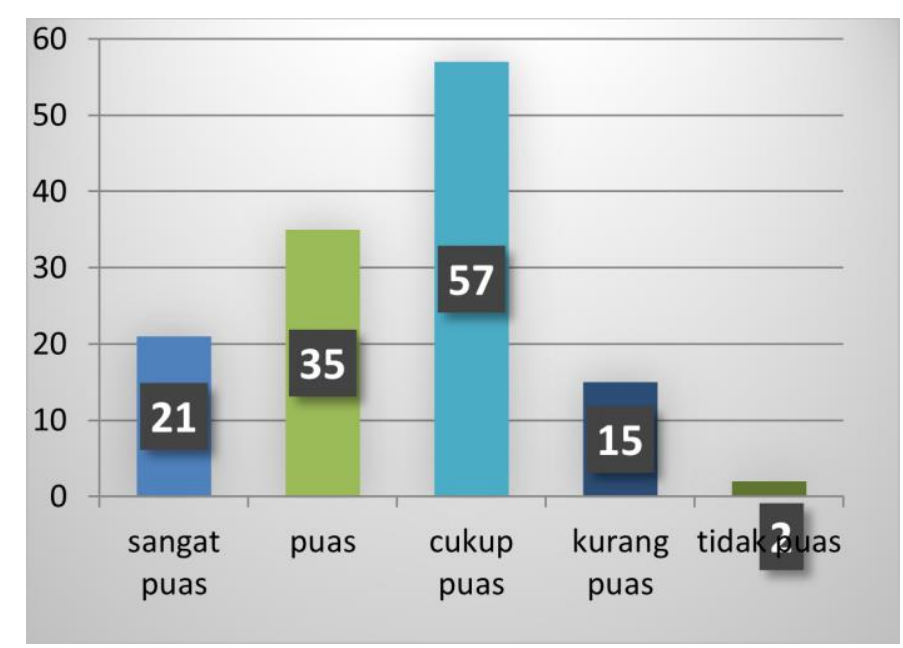

Gambar 7. Diagram Hasil Angket Kepuasan Peserta Didik dalam Menggunakan LMS Google Classroom

Indikator keterampilan komunikasi yang diukur adalah (1) mencari informasi; (2) mendengarkan dan mengamati; (3) menulis ilmiah; (4) merepresentasi informasi; dan (5) mempresentasikan pengetahuan. Proses keterampilan komunikasi ini diobservasi menggunakan sebuah rubrik penilaian dan capaiannya diukur dengan menggunakan tes akhir dan angket melalui google form.

\section{KESIMPULAN DAN SARAN}

\section{Kesimpulan}

Berdasarkan hasil analisis data dan pembahasan, diperoleh kesimpulan bahwa pemanfaatan LMS google classroom untuk pembelajaran IPA jarak jauh pada materi Pesawat Sederhana Jenis Tuas kelas VIII SMP sudah efektif yang dinyatakan dengan partisipasi aktif peserta didik serta menyatakan cukup puas. Pembelajaran jarak jauh yang mengkolaborasikan antara google classroom dengan simulasi PhET ini dapat meningkatkan keterampilan komunikasi peserta didik setelah menggunakan LMS.

\section{Saran}

Bagi peserta didik, pada saat login ke google classroom hendaknya menggunakan akun pribadi dengan nama asli sehingga memudahkan penilaian di akhir pembelajaran.

Bagi guru sebaiknya memastikan kembali akun peserta didik yang sudah masuk ke google classroom sehingga saat pembelajaran berlangsung peserta didik sudah 
Handayani., Sulisworo., Ishafit. - Pemanfaatan Google Classroom...

menggunakan akun pribadinya masing-masing.

\section{DAFTAR PUSTAKA}

A. MacGillivray. (2004). Knowledge management in practice: RRU's Elearning platform development. Roads, Royal Roads University's electronic newsletter.

Andersson, A. \& Grönlund, ̊. (2009). A conceptual framework for eLearning in developing countries: A critical review of research challenges. The Electronic Journal on Information Systems in Developing Countries, 38(8), 1-16.

Dube, S. \& Scott, E. (2014). An empirical study on the use of the Sakai Learning Management System. In Proceedings of the eSkills for Knowledge Production and Innovation Conference. Cape Town, South Africa, 12(3), 101107.

Eom, S. B. (2014). Understanding elearners' satisfaction with learning management systems. Bulletin of the IEEE Technical Committee on Learning Technology, 16(2), 3.

Faith Soykan dan Burak Simsek. (2017). Examining studies on learning management systems in SSCI database: A content analysis study. Procedia Computer Science, 120 (2017), 871-876.

Greenstein, L. (2012). Assessing 21st Century Skills, A Guide to Evaluating Mastery and Authentic Learning. USA : Corwin

Hakim, A.B. (2016). Efektifitas Penggunaan E-Learning Moodle,
Google Classroom Dan Edmodo. |

International Journal of

Technology and Business (IJTB), 2(1), 1-6.

Heeks, R. (2002). Information Systems and Developing Countries: Failure, Success, and Local Improvisations. The Information Society, 18(2), 101112.

Mtebe, J. (2015). Learning Management System success: Increasing Learning Management System usage in higher education in sub-Saharan Africa. International Journal of Education and Development using Information and Communication Technology (IJEDICT), 11(2), 5164.

Nagi, K., Suesawaluk, P., \& U-Lan, P. V. (2008, December). Evaluating Interactivity of eLearning Resources in A Learning Management System (LMS)-A Case Study of MOODLE, An Open Source Platform. In the Fifth International Conference on eLearning for Knowledge-Based Society. Bangkok, Thailand.

Latif, S. (2016). Learning Engagement in Virtual Environment. International Journal of Computer Application, 148(11), 7-13.

Chaw, L. Y., \& Tang, C. M. (2018). What makes learning management systems effective for learning?. Journal of Educational Technology Systems, 47(2), 152169.

Lunenburg, F. C. (2010). Communication: The process, 
Handayani., Sulisworo., Ishafit. - Pemanfaatan Google Classroom...

barriers, and improving effectiveness. Journal Schooling, $1(1), 1-11$.

Mubarrok, M. F. \& Mulyaningsih, S. (2014). Penerapan Pembelajaran Fisika pada Materi Cahaya dengan Media PhET Simulations untuk Meningkatkan Pemahaman Konsep Peserta didik di SMP. Jurnal Inovasi Pendidikan Fisika, 3(1), 76-80.

Naveh, G., Tubin, D. \& Pliskin, N. (2012). Student satisfaction with learning management systems: a lens of critical success factors. Technology, Pedagogy and Education, 21(3), 337-350.

Nurfalah, E. (2019). Optimalisasi ELearning berbasis Virtual Class dengan Google Classroom sebagai Media Pembelajaran Fisika. Physics Education Research Journal, 1(1), 46-55

Ssekakubo, G., Suleman, H. \& Marsden, G. (2013). Designing mobile LMS interfaces: Learners' expectations and experiences. Interactive Technology and Smart Education, 10(2), 147-167.

Swita Amallia Hapsari \& Heri Pamungkas. (2019). Pemanfaatan Google Classroom sebagai Media Pembelajaran Online di Universitas Dian Nuswantoro. WACANA, 18(2), 225 - 233

Tarigan, J. (2011). Factors influencing users satisfaction on eLearning systems. Jurnal Manajemen dan Kewirausahaan, 13(2), 177-188.

Tella, A. (2012). System-related factors that predict students' satisfaction with the Blackboard
Learning System at the University of Botswana. African Journal of Library, Archives and Information Science, 22(1), 41-52.

Tumengkol, A. A. (2020). Pengalaman Pembelajaran Berbasis Blended Learning Mata Kuliah Ilmu Alamiah Dasar Menggunakan Google Classroom Pada Mahapeserta didik Geografi. Jurnal Episentrum, 1(1), 39-43.

Vovides, Y. et al. (2007). The use of e-learning course management systems to support learning strategies and to improve selfregulated learning. Educational Research Review, 2(1), 64-74.

Wang, Y.S., Wang, H.Y. \& Shee, D.Y. (2007). Measuring e-learning systems success in an organizational context: Scale development and validation. Computers in Human Behavior, 23(4), 1792-1808.

Zurimi, S. (2019). Penggunaan ELearning Berbasis Google Classroom Sebagai Media Pendukung dalam Pembelajaran Matematika di MTs Negeri Tulehu. JTRISTE, 6(1), 1-8. 